\title{
Nitramine Anion Fragmentation: A Mass Spectrometric and Ab Initio Study
}

\author{
Jan Florián,* Lan Gao, and Vladimir Zhukhovskyy \\ Department of Chemistry, Loyola University, Chicago, Illinois, USA
}

\author{
Denise K. MacMillan \\ USACE, Engineering Research and Development Center, Environmental Chemistry Branch, Omaha, \\ Nebraska, USA
}

\author{
M. Paul Chiarelli \\ Department of Chemistry, Loyola University, Chicago, Illinois, USA
}

The fragment ion formation characteristics of the radical anions generated from hexahydro1,3,5-trinitrotriazine (RDX) and its three nitroso metabolites were studied using GC/MS with negative chemical ionization (NCI) to understand the fragmentation mechanisms responsible for the formation of the most abundant ions observed in their NCI mass spectra. Ab initio and density functional theory calculations were used to calculate relative free energies for different fragment ion structures suggested by the $\mathrm{m} / \mathrm{z}$ values of the most abundant ions observed in the NCI mass spectra. The NCI mass spectra of the four nitramines are dominated by ions formed by the cleavage of nitrogen-nitrogen and carbon-nitrogen bonds in the atrazine ring. The most abundant anions in the NCI mass spectra of these nitramines have the general formulas $\mathrm{C}_{2} \mathrm{H}_{4} \mathrm{~N}_{3} \mathrm{O}\left(\mathrm{m} / z\right.$ 86) and $\mathrm{C}_{2} \mathrm{H}_{4} \mathrm{~N}_{3} \mathrm{O}_{2}(\mathrm{~m} / z$ 102). The analyses of isotope-labeled standards indicate that these two ions are formed by neutral losses that include two exocylic nitrogens and one atrazine ring nitrogen. Our calculations and observations of the nitramine mass spectra suggest that the $\mathrm{m} / \mathrm{z} 86$ and $\mathrm{m} / \mathrm{z} 102$ ions are formed from either the $(\mathrm{M}-\mathrm{NO})^{-}$or $\left(\mathrm{M}-\mathrm{NO}_{2}\right)^{-}$ fragment anions by a single fragmentation reaction producing neutral losses of $\mathrm{CH}_{2} \mathrm{~N}_{2} \mathrm{O}$ or $\mathrm{CH}_{2} \mathrm{~N}_{2} \mathrm{O}_{2}$ rather than a set of sequential reactions involving neutral losses of $\mathrm{HNO}_{2}$ or $\mathrm{HNO}$ and HCN. (J Am Soc Mass Spectrom 2007, 18, 835-841) @ 2007 American Society for Mass Spectrometry

$\mathrm{H}$ exahydro-1,3,5-trinitrotriazine (RDX, Royal Demolition Explosive) is an explosive widely used for commercial and military purposes since World War II. Contamination of groundwater and soil has resulted from large-scale production and accidental release of RDX into the environment over the years $[1,2]$. RDX is toxic to a variety of organisms in terrestrial $[3,4]$ and aquatic environments [5] and is believed to be carcinogenic in humans [6], although the mechanism of metabolism that might be responsible for the initiation of carcinogenesis remains unknown. As a result, a great deal of effort has been focused on

Published online February 20, 2007

The use of trade, product, or firm names in this report (paper) is for descriptive purposes only and does not imply endorsement by the U.S. Government. The tests described and the resulting data presented herein, unless otherwise noted, were partially obtained from research conducted under the U.S. Army Environmental Quality Technology Program by the U.S. Army Engineer Research and Development Center. Permission was granted by the Chief of Engineers to publish this information.

Address reprint requests to Dr. M. Paul Chiarelli, Department of Chemistry, Loyola University, 1068 W Sheridan Rd., Chicago, IL 60626. E-mail: mchiare@luc.edu

* Institute of Physics, Charles University, Prague, Czech Republic. developing methods for the analysis of RDX and its metabolites in different environmental matrices.

Studies of the microbe-induced metabolism of RDX may provide some insight into its adverse health effects in humans. The biodegradation of RDX has been studied under a number of different conditions in the hopes of identifying cost-effective methods of remediating explosives-contaminated sites [7-13]. One of the major anaerobic metabolism pathways involves the sequential reduction of the exocyclic nitro to nitroso groups [7, 8] to form three distinct metabolites that contain up to three nitrogen-nitrosonitrogen bonds: hexahydro-1nitroso-3,5-dinitro-1,3,5-triazine (MNX), hexahydro-1,3dinitroso-5-nitro-1,3,5-triazine (DNX), and hexhydro1,3,5-trinitroso-1,3,5-triazine (TNX). Reduction of RDX to MNX was suggested as a potential first step in the formation of ring-cleavage products under anaerobic microbial conditions [14], whereas microbiological degradation under aerobic conditions was suggested to proceed through an initial denitration step [13]. Compounds containing nitrogen-nitrosonitrogen bonds have been previously identified as carcinogens [15], suggesting that the formation of one of these 
three RDX metabolites may be a putative step in the initiation of cancer. The toxicity of MNX to SpragueDawley rats was recently shown to be similar in magnitude and adverse effects to that of RDX [16]. Studies with deer mice suggest potential reproductive effects arising from TNX exposure through drinking water [17]. The goal of this study is to identify the structures of fragment ions that may be used to identify and quantify these three metabolites with gas chromatography/mass spectrometry (GC/MS) negative chemical ionization (NCI) analyses.

Analytical methods for RDX and other explosives can be grouped into two categories. One group of methods is used for identification of explosives in complex matrices for forensic purposes. Several mass spectrometry techniques based on atmospheric pressure chemical ionization [18-21] and electrospray ionization [22-24] have been developed to identify RDX and other explosives in post-detonation residues. A number of different sensors have also been developed to screen the atmosphere for explosives [25].

The second set of analytical methods is designed to assess environmental contamination brought about by the discharge of explosives into the environment. Highperformance liquid chromatography (HPLC) with UV detection according to the Environmental Protection Agency Method 8330 [26] is widely used for environmental analysis of explosives, but many laboratories are now using GC coupled with electron capture detection (ECD) as described in Method 8095 [27] for increased sensitivity, given the large electron affinities of many explosives [28-30]. Analytical methods based on GC/MS with NCI offer sensitivity similar to that based on GC/ECD but yield more structural information. GC/MS and NCI have previously been used to analyze RDX [31, 32], but no mechanistic studies of the ion formation processes for this compound have been carried out to date.

RDX is quantified with GC/MS-NCI by monitoring the fragment ions of $m / z 102$ and $m / z 129$. The empirical formulas of these anions have been identified as $\mathrm{C}_{2} \mathrm{H}_{4} \mathrm{~N}_{3} \mathrm{O}_{2}{ }^{-}$and $\mathrm{C}_{3} \mathrm{H}_{5} \mathrm{~N}_{4} \mathrm{O}_{2}{ }^{-}$, respectively, but their structures are not known [33]. The goals of this study are to determine the fragmentation pathways and fragment ion structures derived from NCI of RDX and its nitroso metabolites. Ab initio quantum chemical calculations were carried out to identify the most probable structures of the most abundant fragment ion species suggested by the NCI mass spectra of RDX, its nitroso metabolites, and different isotopically labeled compounds. Previous computational studies at the ab initio level were successful in predicting the structures of the decomposition products formed during the detonation of (neutral) RDX [34-38], but did not address fragmentation pathways for the anions observed in the NCI mass spectra of RDX or its nitroso metabolites.

\section{Experimental}

\section{Compounds}

MNX, ${ }^{15} \mathrm{~N}_{3}-\mathrm{MNX}, \mathrm{DNX}, \mathrm{TNX}$, and ${ }^{15} \mathrm{~N}_{3}$-RDX were obtained from Dr. Ron Spanggord (SRI International, Menlo Park, CA USA). RDX was purchased from Sigma Chemical (St. Louis, MO, USA) and ${ }^{13} C_{3}$-RDX was acquired from Cambridge Isotope Laboratories (Andover, MA, USA). All compounds were used without further purification. Structures of these compounds are shown in Figures 1 and 2.

\section{Instrumentation}

A ThermoFinnigan TraceGC/MS (San Jose, CA, USA) equipped with negative chemical ionization source was used for all analyses. The instrument was equipped with a Rtx-5MS column, $15 \mathrm{~m} \times 0.25 \mathrm{~mm}$ (Restek Corp., Bellefonte, PA, USA). Picomolar quantities of analyte were analyzed in the splitless mode. The GC was heated from 40 to $250{ }^{\circ} \mathrm{C}$ at a rate of $30^{\circ} \mathrm{C} / \mathrm{min}$. The injector temperature was $150^{\circ} \mathrm{C}$; the source temperature was $200{ }^{\circ} \mathrm{C}$. The flow rate of methane $\mathrm{CI}$ gas was optimized to $1.5 \mathrm{~mL} / \mathrm{min}$ using the manufacturer's software. The electron energy was $70 \mathrm{eV}$.

\section{Computational Methods}

The relative free energies of the product ions formed by the decomposition of the RDX and TNX radical anions in the gas phase were calculated at the MP2/AUG-ccpVDZ/ /B3LYP/6-31G(d) level of ab initio quantum mechanical theory. At this level, the energy is determined by the second-order perturbation theory (MP2) using the correlation-consistent polarized valence double-zeta basis set $^{\circ}$ that $^{\circ}$ is ${ }^{\circ}$ augmented ${ }^{\circ}$ by $^{\circ}$ diffuse $^{\circ}$ functions ${ }^{\circ}[39] .{ }^{\circ}$ This energy is evaluated for geometries determined using Becke's three-parameter hybrid exchange functional (B3) that is combined with the correlation functional of Lee, Yang, ${ }^{\circ}$ and ${ }^{\circ} \operatorname{Parr}^{\circ}(\mathrm{LYP})^{\circ}\left[40,{ }^{\circ} 41\right] .^{\circ}{ }^{\circ}$ These ${ }^{\circ}$ functionals ${ }^{\circ}$ operate on electron density, which is expanded using the $6-31 \mathrm{G}(\mathrm{d})$ polarized split-valence basis set.

The rotational and vibrational contributions to the enthalpy and entropy were evaluated at $298 \mathrm{~K}$ using rigid-rotor and harmonic-oscillator approximations, and vibrational energy levels calculated at the HartreeFock (HF) level using the 6-31G(d) basis set. Calculations for open-shell systems were carried out using unrestricted MP2, B3LYP, and HF Hamiltonians. Relative free energies for isomers of the TNX radical anion decomposition products of $\mathrm{m} / \mathrm{z} 86$ and $\mathrm{m} / \mathrm{z} 113$ were determined by using the Gaussian-3 (G3) procedure of Curtiss ${ }^{\circ} d^{\circ}{ }^{\circ}$ coworkers 942$]$. This procedure $^{\circ}$ extrapolates series of high-level ab initio calculations to the full-CI/ complete basis set accuracy. All quantum chemical calculations were carried out using the Gaussian 03 program ${ }^{\circ}[43]$. 


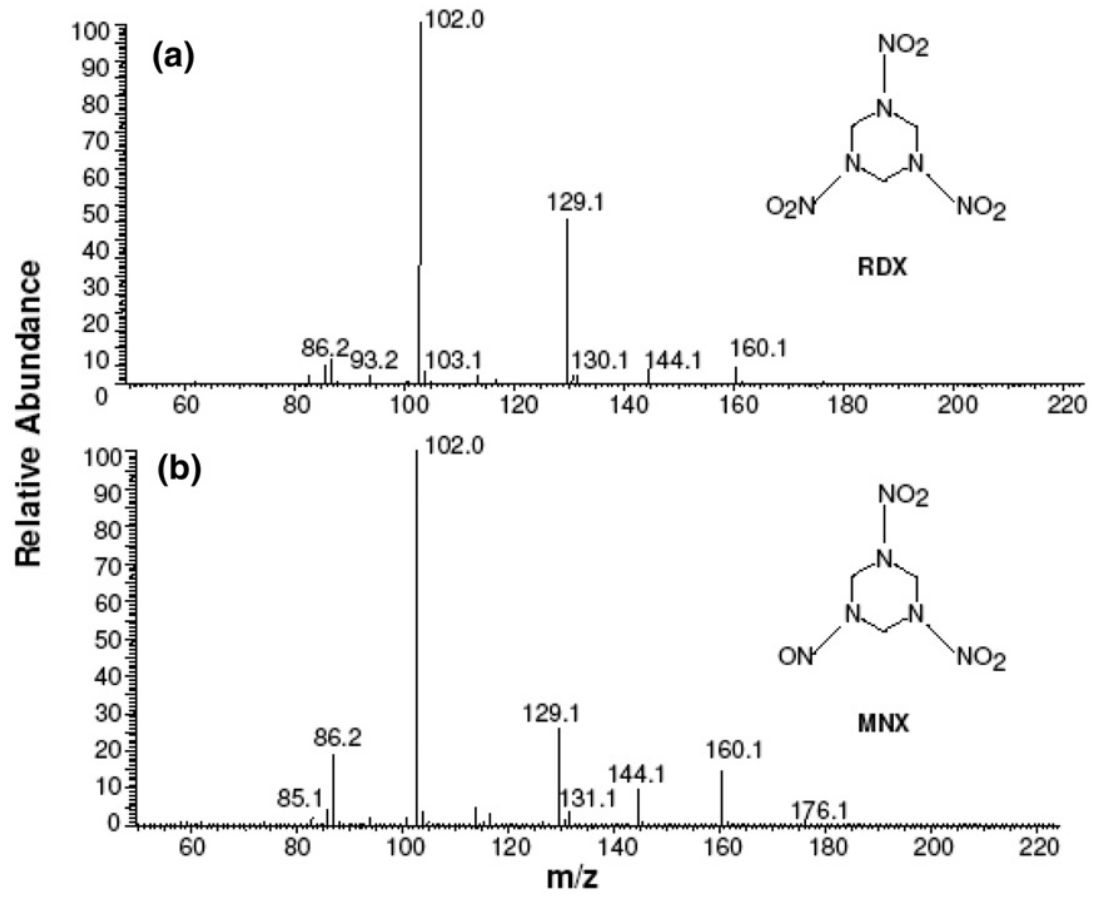

Figure 1. Full-scan NCI mass spectra of (a) hexahydro-1,3,5-trinitrotriazine (RDX) and (b) hexahydro-1-nitroso-3,5-dinitro-1,3,5-triazine (MNX).

\section{Results and Discussion}

\section{Fragmentation of Nitramine Anions}

Full-scan NCI mass spectra of the four nitramines in this ${ }^{\circ}$ study ${ }^{\circ}$ are $^{\circ}$ presented ${ }^{\circ}{ }^{\circ}{ }^{\circ}$ Figures ${ }^{\circ} 1^{\circ}$ and ${ }^{\circ} 2 .^{\circ}$ Abundant fragment ions are formed by the homolytic cleavage of the exocyclic $\mathrm{NO}_{\mathrm{x}}$ groups. Further decomposition steps involve cleavage of $\mathrm{C}-\mathrm{N}$ bonds in the triazine ring.

Fragment ions formed by the cleavage of a single exocyclic nitrogen-nitrogen bond, $\left(\mathrm{M}-\mathrm{NO}_{\mathrm{x}}\right)^{-}$, become more abundant as the number of $\mathrm{NO}$ groups attached to the atrazine ring increases. The NCI mass spectrum of

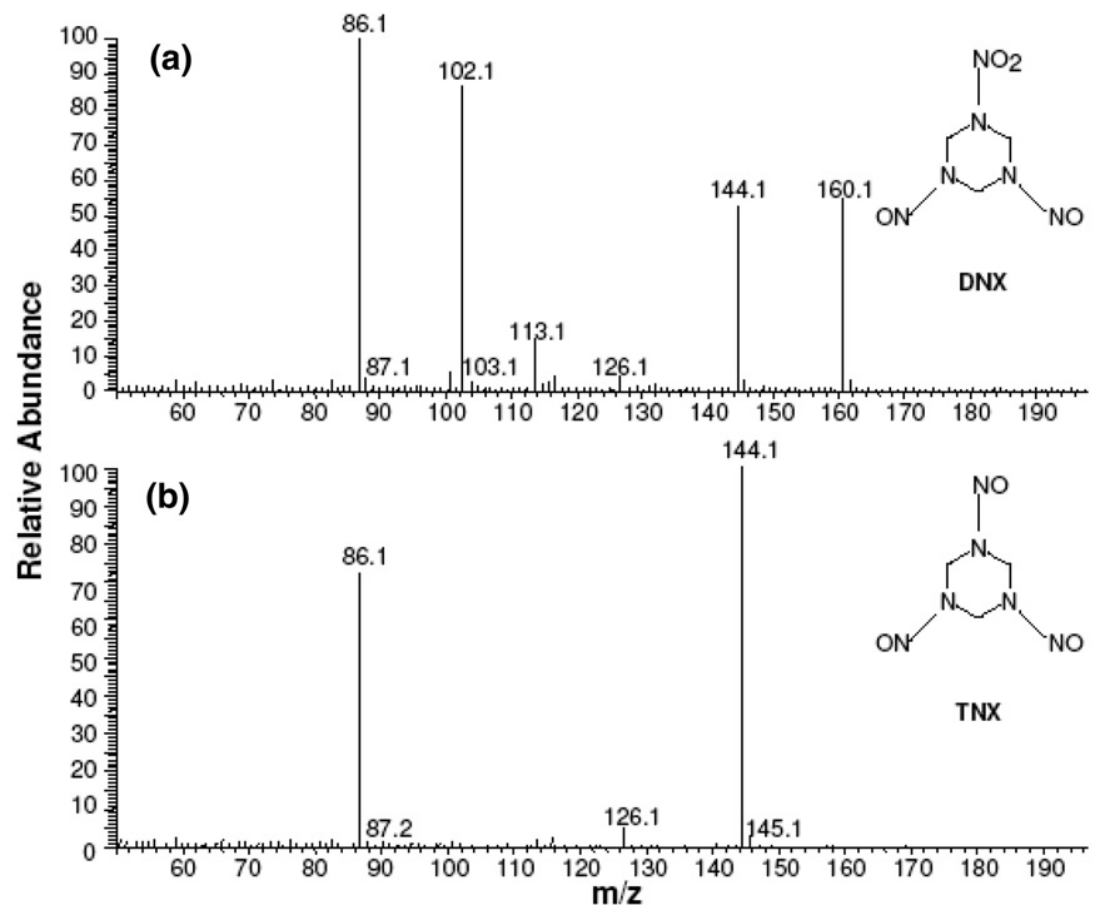

Figure 2. Full-scan NCI mass spectra of (a) hexahydro-1,3-dinitroso-5-nitro-1,3,5-triazine (DNX) and (b) hexhydro-1,3,5-trinitroso-1,3,5-triazine (TNX). 


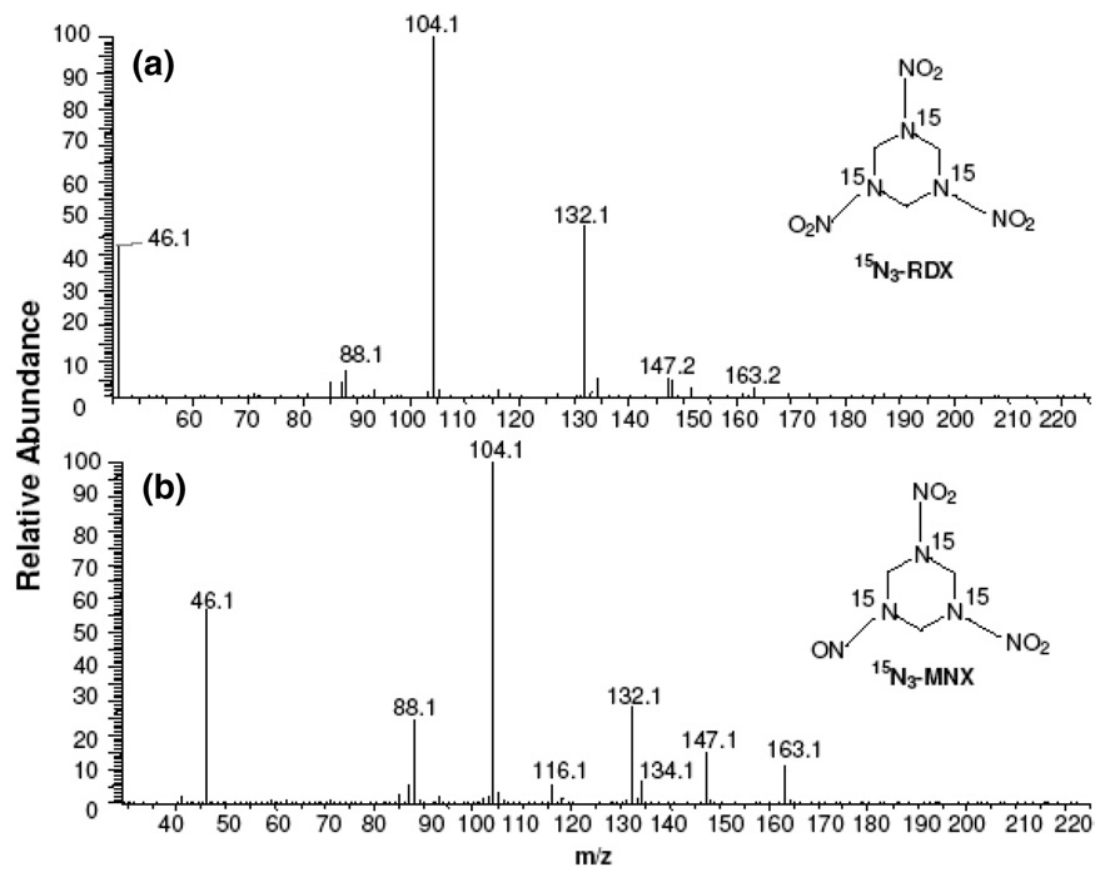

Figure 3. Full-scan NCI mass spectra of (a) ring-labeled ${ }^{15} \mathrm{~N}_{3}$-hexahydro-1,3,5-trinitrotriazine (RDX) and (b) ring-labeled ${ }^{15} \mathrm{~N}_{3}$-hexahydro-1-nitroso-3,5-dinitro-1,3,5-triazine (MNX).

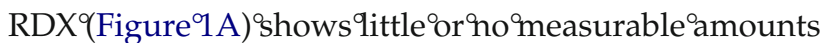
of an $\left(\mathrm{M}-\mathrm{NO}_{2}\right)^{-}$ion $(\mathrm{m} / \mathrm{z} 176)$, whereas $\mathrm{MNX}$, which has one nitroso group, yields an $\left(\mathrm{M}-\mathrm{NO}_{2}\right)^{-}$of $\mathrm{m} / \mathrm{z} 160$ with $20 \%$ relative abundance. DNX, a compound with two nitroso groups and one nitro group, yields $(\mathrm{M}-\mathrm{NO})^{-}$and $\left(\mathrm{M}-\mathrm{NO}_{2}\right)^{-}$ions at roughly $60 \%$ relative abundance $(\mathrm{m} / \mathrm{z} 160$ and $\mathrm{m} / \mathrm{z} 144$, respectively, in Figure $\left.{ }^{\circ} 2 \mathrm{~A}\right) .^{\circ}{ }^{\circ} \mathrm{The}^{\circ}$ base $^{\circ}$ peak $^{\circ}{ }^{\circ}{ }^{\circ}$ the ${ }^{\circ}$ Figure $^{\circ} 2 \mathrm{~B}^{\circ} \mathrm{NCI}^{\circ}$ spectrum of TNX, a compound that has three nitroso groups, is the $(\mathrm{M}-\mathrm{NO})^{-}$ion of $m / z 144$.

The presence of the $m / z 102$ ion in the mass spectra of RDX $^{\circ}$ and $^{\circ} \mathrm{MNX}^{\circ}\left(\text { Figure }^{\circ} 1 \mathrm{~A}^{\circ} \text { and }{ }^{\circ} \mathrm{B}\right)^{\circ}$ suggests ${ }^{\circ}$ that ${ }^{\circ}$ it ${ }^{\circ}$ may be formed by a loss of HCN from the $\mathrm{m} / \mathrm{z} 129$ ion, $\mathrm{C}_{3} \mathrm{H}_{5} \mathrm{~N}_{4} \mathrm{O}_{2}^{--}$, that contains a single $\mathrm{NO}_{2}$ group. Neither fragment ion is observed in the NCI mass spectrum of TNX, which has no appended nitro groups, suggesting that at least one $\mathrm{NO}_{2}$ group is lost when the $\mathrm{m} / \mathrm{z} 102$ ion is formed. The $\mathrm{m} / \mathrm{z} 129$ ion may result from loss of $\mathrm{HNO}_{2}$ and $\mathrm{NO}_{2}$ from RDX or $\mathrm{HNO}_{2}$ and $\mathrm{NO}$ from MNX. The $\mathrm{m} / \mathrm{z} 86$ ion is observed in all four spectra, but in greater abundance in the spectra of DNX and TNX (Figure $\left.2 \mathrm{~A}^{\circ}{ }^{\circ}{ }^{\circ} \mathrm{B}\right)^{\circ}$ than ${ }^{\circ}{ }^{\circ}{ }^{\circ}$ the ${ }^{\circ}$ spectra ${ }^{\circ}$ of ${ }^{\circ} \mathrm{RDX}{ }^{\circ}$ and ${ }^{\circ} \mathrm{MNX}$

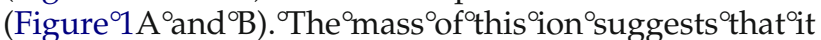
contains one less oxygen atom than the $\mathrm{m} / \mathrm{z} 102$ that is prevalent in the NCI spectra of RDX and MNX.

The goals of this study are to determine the fragmentation pathways that promote the formation of the most abundant ions (summarized above) in the NCI mass spectra of RDX and its N-nitroso products that may serve as targets for single-ion monitoring analyses. The mechanisms of formation for these fragment anions were investigated by calculating the free energies of formation of the structures consistent with the empiri- cal formulas of these ions suggested by their $\mathrm{m} / \mathrm{z}$ values. $\mathrm{NCI}$ analyses of $\mathrm{C}-13$ and $\mathrm{N}-15$ ring-labeled nitramines were carried out to clarify these fragmentation pathways as well.

The presence of the ion of $\mathrm{m} / \mathrm{z} 132$ in the NCI mass spectra of ring-labeled standards, ${ }^{15} \mathrm{~N}_{3}$-MNX and ${ }^{15} \mathrm{~N}_{3}$ RDX $^{\circ}$ (Figure 3 ), ${ }^{\circ}$ suggests ${ }^{\circ}$ that ${ }^{\circ}$ none $^{\circ}$ of ${ }^{\circ}$ the ${ }^{\circ}$ atrazine ${ }^{\circ}$ ring nitrogens is involved in the $\mathrm{HNO}$ or $\mathrm{HNO}_{2}$ neutral losses that lead to the formation of $\mathrm{m} / \mathrm{z} 129$ observed in the ${ }^{\circ}$ Figure ${ }^{\circ} 1^{\circ}$ mass ${ }^{\circ}$ spectra. ${ }^{\circ}$ The ${ }^{\circ}$ two ${ }^{\circ}$ most ${ }^{\circ}$ abundant ${ }^{\circ}$ ions observed in the NCI mass spectra of the isotopically labeled ${ }^{\circ}$ species ${ }^{\circ}$ hown ${ }^{1}{ }^{\circ}$ Figure $3^{\circ}$ discussed here are the $\mathrm{m} / \mathrm{z} 104$ and $\mathrm{m} / \mathrm{z} 132$ anions. The relative abundances and $\mathrm{m} / \mathrm{z}$ values of these ions suggest their empirical formulas are the same as the ions of $m / z 102\left(\mathrm{C}_{2} \mathrm{H}_{4} \mathrm{~N}_{3} \mathrm{O}_{2}^{-}\right)$ and $m / z 129\left(\mathrm{C}_{3} \mathrm{H}_{5} \mathrm{~N}_{4} \mathrm{O}_{2}^{-}\right)$in the mass spectra of the unlabeled ${ }^{\circ} \mathrm{RDX}^{\circ}$ and $^{\circ} \mathrm{MNX}^{\circ}\left(\right.$ Figure $\left.^{\circ} 1\right) .{ }^{\circ}$ The $^{\circ}$ presence $^{\circ}$ of the ion of $\mathrm{m} / \mathrm{z} 104$ in the NCI mass spectra of the ring-labeled species suggests that one of the ring nitrogens is incorporated in the neutral loss that leads to the formation of the ion of $\mathrm{m} / \mathrm{z} 102$ observed in the NCI mass spectra of RDX and MNX.

The NCI mass spectrum of the ring-labeled ${ }^{13} \mathrm{C}_{3}$-RDX (not shown) is nearly identical to that of the ${ }^{15} \mathrm{~N}_{3^{-}}$ labeled RDX, consistent with the supposition that one atrazine ring nitrogen is lost in the formation of the $\mathrm{m} / \mathrm{z}$ $102^{\circ}{ }^{\circ}{ }^{\circ} .{ }^{\circ}$ The $^{\circ}$ mass $^{\circ}$ spectra ${ }^{\circ}$ of $^{\circ} \mathrm{DNX}^{\circ}$ and ${ }^{\circ} \mathrm{TNX}^{\circ}\left(\right.$ Figure $\left.^{\circ} 2\right)$ suggest that analogous fragmentation pathways based on consecutive losses of $\mathrm{HNO}$ and HCN may not be prevalent for these compounds, given the low relative abundance of the $\mathrm{m} / \mathrm{z} 113$ anion that might serve as a precursor (by loss of $\mathrm{HCN}$ ) to the $\mathrm{m} / \mathrm{z} 86$ anion. To gain a better understanding of these fragmentation path- 

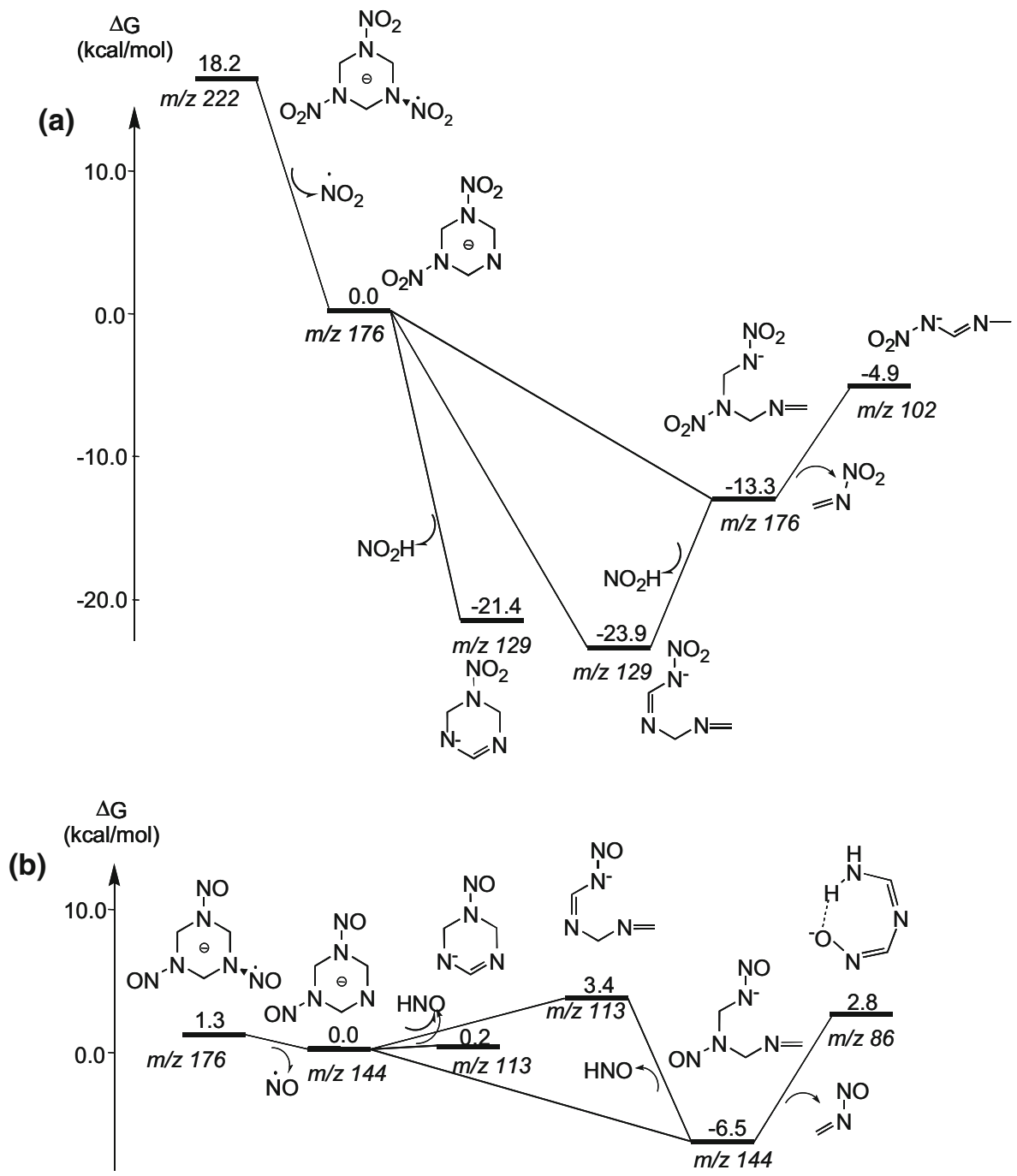

Figure 4. Relative free energies for fragment anion structures formed from (a) RDX and (b) TNX during $\mathrm{NCI}$ of nitramines.

ways, the free energies of formation were calculated for several structures consistent with each of $\mathrm{m} / \mathrm{z}$ values of the ions observed in the NCI mass spectra.

\section{Free Energy Calculations}

Free energies of several different structures derived from an empirical formula specified by a particular $\mathrm{m} / \mathrm{z}$ value were calculated for the major ions observed in the $\mathrm{NCI}$ mass spectra of these nitramines. The relative free energies were calculated using the structures of the $\mathrm{M}-\mathrm{NO}_{\mathrm{x}}$ fragment anions of RDX $(\mathrm{m} / z$ 176) and TNX $(\mathrm{m} / \mathrm{z} 144)^{\circ}$ presented ${ }^{\circ}{ }^{\circ}{ }^{\circ}$ Figure $^{\circ} 4^{\circ}$ as $^{\circ}$ reference $^{\circ}$ points ${ }^{\circ}(\Delta G$ $=0)$. The free energies of 11 different isomers representing the $\mathrm{m} / \mathrm{z} 86$ ion (observed in the spectra of the three nitramines ${ }^{\circ}$ with nitroso ${ }^{\circ}$ groups in ${ }^{\circ}$ Figures 1 and 2 ) were $^{\circ}$ calculated $^{\circ}$ and $^{\circ}$ are $^{\circ}$ presented $^{\circ}$ in $^{\circ}$ Figure $^{\circ} 5^{\circ}$ as ${ }^{\circ}$ an example. The ion structures with the lowest relative free energies consistent with the $\mathrm{m} / \mathrm{z}$ values of the most abundant ${ }^{\circ}$ ions $^{\circ}$ observed $^{\circ}$ in $^{\circ}$ the ${ }^{\circ}$ Figures $^{\circ} 1^{\circ}$ and $^{\circ} 2^{\circ} \mathrm{NCI}$ mass ${ }^{\circ}$ spectra ${ }^{\circ}$ are $^{\circ}$ shown $^{\circ}{ }^{\circ}{ }^{\circ}$ Figure $^{\circ} 4 .^{\circ}{ }^{\circ}$ Calculations ${ }^{\circ}$ suggest that cleavage of the $\mathrm{N}-\mathrm{NO}_{2}$ bond is favored over the $\mathrm{N}-\mathrm{NO}$ bond by $16.9 \mathrm{kcal} / \mathrm{mol}$. These results are consistent with observed relative abundances of $\left(\mathrm{M}-\mathrm{NO}_{2}\right)^{-}$and $(\mathrm{M}-\mathrm{NO})^{-}$fragment anions in the NCI mass ${ }^{\circ}$ pectra ${ }^{\circ}{ }^{\circ} \mathrm{MNX}^{\circ}$ and ${ }^{2} \mathrm{DNX}^{\circ}$ (Figures $1 \mathrm{~B}^{\circ}$ and $2 \mathrm{~A}$ ) ${ }^{\circ}$ and are also consistent with the greater calculated equilibrium bond length of the $\mathrm{N}-\mathrm{NO}_{2}$ bond relative to the $\mathrm{N}-\mathrm{NO}$ bond. The $\mathrm{N}-\mathrm{NO}$ bond is shorter in the radical anion because the Mulliken electron spin density is shared between the two nitrogen atoms, whereas the electron spin density is found almost exclusively on the atrazine ring nitrogen in the $\mathrm{N}-\mathrm{NO}_{2}$ bond. Our calculations suggest that once the nitrogen-nitrogen bond is broken, the negative charge density will be centered on the atrazine ring nitrogen forming a closed-shell anion.

The relative abundance of the $\left(\mathrm{M}-\mathrm{NO}_{2}\right)$ anion is observed to increase as the number of exocyclic NO groups attached to the atrazine ring increases, suggesting that the $\left(\mathrm{M}-\mathrm{NO}_{2}\right)$ anions become more stable as the 
(1)<smiles>C=NC[N-]N=O</smiles>

0.0

(4)<smiles>O=[N+]1CNCN1</smiles>

(7)<smiles>[O-]N1CNC=N1</smiles>

20.5

(10)

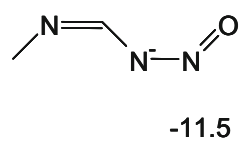

(2)<smiles>O=NN1C[N-]C1</smiles>

41.4

(5)<smiles>C=NC=N[N-]O</smiles>

(8)<smiles>N=C[N-]CN=O</smiles>

6.9
(3)<smiles>C1N=NOC[N-]1</smiles>

20.5

(6)<smiles>ON1CN=CN1</smiles>

(9)<smiles>N/C=N\C=N/[O-]</smiles>

$-25.2$
(11)

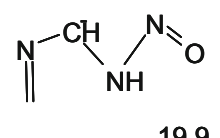

19.9

Figure 5. Relative free energies $(\mathrm{kcal} / \mathrm{mol})$ for different structures consistent with the empirical formula $\left(\mathrm{C}_{2} \mathrm{H}_{4} \mathrm{~N}_{3} \mathrm{O}\right)$ of the $\mathrm{m} / \mathrm{z} 86$ ion.

number of exocyclic NO groups on the atrazine ring increases. This is consistent with the relative free energies associated ${ }^{\circ}$ with $^{\circ}$ the ${ }^{\circ}$ structures $^{\circ}$ given ${ }^{\circ}{ }^{\circ}{ }^{\circ}$ Figure $^{\circ} 4$. $^{\circ}$ The ${ }^{\circ}$ loss of HONO from the $\left(\mathrm{M}-\mathrm{NO}_{\mathrm{x}}\right)$ fragment anions is favored over the loss of $\mathrm{HNO}$ by as much as $27.3 \mathrm{kcal} / \mathrm{mol}$. This is consistent with the observed relative abundances of the $m / z 176, m / z 160$, and $m / z 144$ ions seen in the mass spectra of ${ }^{\circ} \mathrm{MNX}{ }^{\circ}$ and ${ }^{\circ} \mathrm{DNX}{ }^{\circ}$ in $^{\circ}$ Figures $^{\circ} 1^{\circ}$ and ${ }^{\circ} 2$.

The relative free energies of the most stable structures in ${ }^{\circ}$ Figure ${ }^{\circ} 4^{\circ}$ and $^{\circ}$ the $^{\circ}$ lack $^{\circ}$ of $^{\circ}$ any $^{\circ}$ significant ${ }^{\circ}$ abundance ${ }^{\circ}$ of $m / z 113$ ion in the NCI mass spectra of TNX and other nitroso-containing compounds suggest that the fragment anions with the empirical formulas $\mathrm{C}_{3} \mathrm{H}_{5} \mathrm{~N}_{4} \mathrm{O}_{\mathrm{x}}(\mathrm{m} / z 113$ and $m / z$ 129) and $\mathrm{C}_{2} \mathrm{H}_{4} \mathrm{~N}_{3} \mathrm{O}_{x}(m / z 86$ and $m / z$ 102) are formed by competing losses of $\mathrm{HNO}_{x}$ and $\mathrm{CH}_{2} \mathrm{~N}_{2} \mathrm{O}_{x}$, respectively, from the $\left(\mathrm{M}-\mathrm{NO}_{\mathrm{x}}\right)$ anion rather than by consecutive losses of $\mathrm{HNO}_{x}$ and $\mathrm{HCN}$. The proposed mechanism $^{\circ}$ of $^{\circ}$ fragmentation $^{\circ}$ is ${ }^{\circ}$ summarized $^{\circ}$ in $^{\circ}$ Figure $^{\circ} 6$. The relative free energies of the $\mathrm{C}_{3} \mathrm{H}_{5} \mathrm{~N}_{4} \mathrm{O}_{2}(\mathrm{~m} / \mathrm{z}$ 129) ions in $^{\circ}$ Figure $^{\circ} 4^{\circ}$ are $^{\circ}$ at $^{\circ}$ least $^{\circ} 16.5^{\circ} \mathrm{kcal} / \mathrm{mol}^{\circ}$ less $^{\circ}$ than $^{\circ}$ the $\mathrm{C}_{2} \mathrm{H}_{4} \mathrm{~N}_{3} \mathrm{O}_{2}$ ion $(\mathrm{m} / \mathrm{z}$ 102). Also, the activation energy associated with the $\mathrm{HCN}$ loss pathway (e.g., $m / z 129 \rightarrow m / z 102$ in $^{\circ}$ Figure $\left.^{\circ} 1\right)^{\circ}$ is $^{\circ}$ at $^{\circ}$ least $^{\circ} 15^{\circ} \mathrm{kcal} / \mathrm{mol}^{\circ}$ larger $^{\circ}$ than $^{\circ}$ the activation energy required for the loss of $\mathrm{CH}_{2} \mathrm{~N}_{2} \mathrm{O}_{x}$ from the $\left(\mathrm{M}-\mathrm{NO}_{\mathrm{x}}\right)$ anion. These computational results are consistent with the NCI mass spectra of TNX where only two major fragment ions are observed: the $(\mathrm{M}-\mathrm{NO})$ anion of $m / z 144$ and the $\mathrm{C}_{2} \mathrm{H}_{4} \mathrm{~N}_{3} \mathrm{O}^{\circ}$ anion ${ }^{\circ}{ }^{\circ} \mathrm{m} / \mathrm{z} 8^{\circ}$ (Figure 4 ).

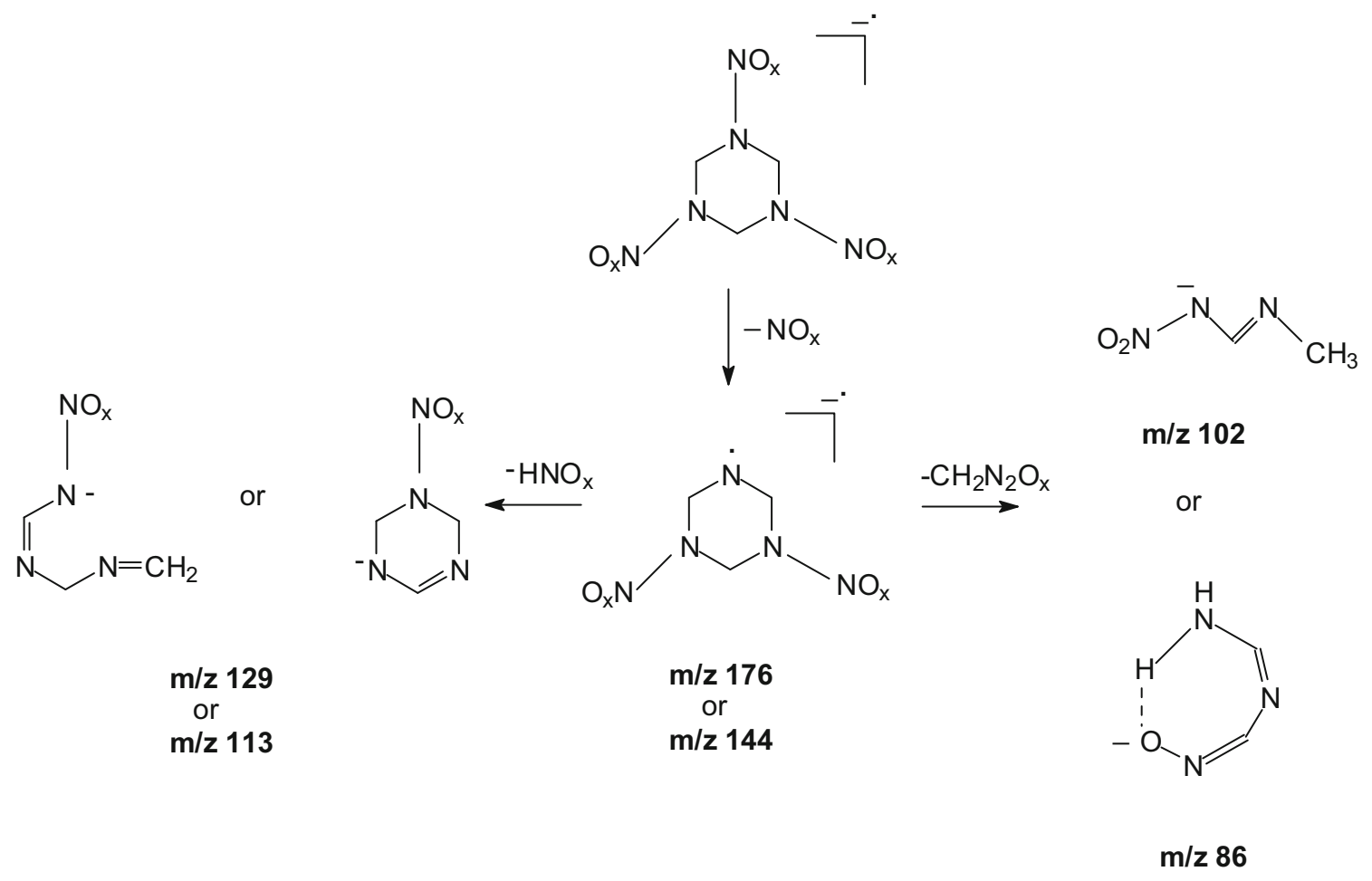

Figure 6. Proposed mechanism of fragmentation of RDX and its nitroso metabolites (MNX, DNX, and TNX) after negative chemical ionization. 


\section{Conclusion}

The NCI mass spectra of RDX and its three nitroso metabolites were studied to elucidate the fragmentation mechanisms associated with the most abundant ions observed. Free energies of formation for several structures consistent with the $\mathrm{m} / \mathrm{z}$ values of the anions observed in the mass spectra were calculated to gain insight into the mechanism of fragmentation. The lowest energy structures and the overall appearance of the mass spectra suggest a fragmentation mechanism where $\mathrm{C}_{2} \mathrm{H}_{4} \mathrm{~N}_{3} \mathrm{O}_{x}$ anions are formed from the $\left(\mathrm{M}-\mathrm{NO}_{\mathrm{x}}\right)$ fragment anions by neutral loss of $\mathrm{CH}_{2} \mathrm{~N}_{2} \mathrm{O}_{\mathrm{x}}$ rather than by sequential losses of $\mathrm{HNO}_{\mathrm{x}}$ and $\mathrm{HCN}$.

\section{References}

1. Jenkins, T. F.; Hewitt, A. D.; Grant, C. L.; Thiboutot, S.; Ampleman, G.; Walsh, M. E.; Ranney, T. A.; Ramsey, C. A.; Palazzo, A. J.; Pennington, J. C. Identity and Distribution of Residues of Energetic Compounds at Army Live-fire Ranges. Chemosphere 2006, 63, 1280-1290.

2. Haas, R.; Schreiber, I.; von Löw, E.; Stork, G. Conception for the Investigation of Contaminated Munitions Plants. 2. Investigation of Former RDX Plants and Filling Stations. Frensius J. Anal. Chem. 1990, $338,41-45$.

3. McLellan, W.; Hartley, W. R.; Brower, M. Health Advisory for Hexahydro1,3,5-trinitro-1,3,5-triazine. Technical Report PB90-273533; Office of Drinking Water, U. S. Environmental Protection Agency: Washington, DC, 1988.

4. Robidoux, P. Y.; Svendsen, C.; Caumartin, J.; Hawari, J.; Ampleman, G.; Thiboutot, S.; Weeks, J. M.; Sunahara, G. I. Chronic Toxicity of Energetic Compounds in Soil Determined Using the Earthworm (Eisenia andrei) Reproduction Test. Environ. Toxicol. Chem. 2000, 19, 1764-1773.

5. Talmage, S. S.; Opresko, D. M.; Maxwell, C. J.; Welsh, C. J. E.; Cretella, F. M.; Reno, P. H.; Daniel, F. B. Nitroaromatic Munition Compounds: Environmental Effects and Screening Values. Rev. Environ. Contam. Toxicol. 1999, 161, 1-156.

6. Faust, R. A. Toxicity Summary for Hexahydo-1,3,5-trinitro-1,3,5-triazine (RDX). Report prepared for Oak Ridge Reservational Environmental Restoration Program, 1994 (cira.ornl.gov/documents/RDX.pdf).

7. McCormick, N. G.; Cornell, J. H.; Kaplan, A. M. Biodegradation of Hexahydro-1,3,5-trinitro-1,3,5-triazine. Appl. Environ. Microbiol. 1981, $42,817-823$.

8. McCormick, N. G.; Cornell, J. H.; Kaplan, A. M. The anaerobic biotransformation of RDX, HMX, and their acetylated derivatives. Technical Report No. 85-007; US Army Natick Research, Development, and Engineering Center; 1985.

9. Bhusshan, B.; Halasz, A.; Hawari, J. Effect of Iron(III), Humic Acids and Anthraquinone-2,6-disulfonate of the Biodegradation of Cyclic Nitramines by Clostridium sp. EDB2. J. Appl. Microbiol. 2006, 100, 555-563.

10. Thompson, K. T.; Crocker, F. H.; Fredrickson, H. L. Mineralization of the Cyclic Nitramine Explosive Hexahydro-1,3,5-trinitro-1,3,5-triazine by Gordonia and Williamsia spp. Appl. Environ. Microbiol. 2005, 71, $8265-8272$.

11. Rylott, E. L.; Jackson, R. G.; Edwards, J.; Womack, G. L.; Seth-Smith, H. M. B.; Rathbone, D. A.; Strand, S. E.; Bruce, N. C. An Explosivedegrading Cytochrome P450 Activity and Its Targeted Application for the Phytoremediation of RDX. Nat. Biotechnol. 2006, 24, 216-219.

12. Hawari, J.; Halasz, A.; Sheremata, T.; Beaudet, S.; Groom, C.; Paquet, L.; Rhofir, C.; Ampleman, G.; Thiboutot, S. Characterization of Metabolites during Biodegradation of Hexahydro-1,3,5-trinitro-1,3,5-triazine (RDX) with Municipal Anaerobic Sludge. Appl. Environ. Microbiol. 2000, 66, 2652-2657.

13. Fournier, D.; Halasz, A.; Spain, J.; Fiurasek, P.; Hawari, J. Determination of Key Metabolites during Biodegradation of Hexahydro-1,3,5-trinitro1,3,5-triazine with Rhodococcus sp. Strain DN22. Appl. Environ. Microbiol. 2002, 68, 166-172.

14. Halasz, A.; Spain, J.; Paquet, L.; Beaulieu, C.; Hawari, J. Insights into the Formation and Degradation Mechanisms of Methylenedinitramine during the Incubation of RDX with Anaerobic Sludge. Environ. Sci. Technol. 2002, 36, 633-638.

15. Hecht, S. S. Tobacco Carcinogens, Their Biomarkers and Tobaccoinduced Cancer. Nat. Rev. Cancer 2003, 3, 733-744.

16. Meyer, S. A.; Marchand, A. J.; Hight, J. L.; Roberts, G. H.; Escalon, L. B.; Inouye, L. S.; MacMillan, D. K. Up-and-down Procedure (UDP) Determinations of Acute Oral Toxicity of Nitroso Degradation Products of Hexahydro-1,3,5-trinitro-1,3,5-triazine (RDX). J. Appl. Toxicol. 2005, 25, 427-434.

17. Smith, J. N.; Pan, X.; Gentles, A.; Smith, E. E.; Cox, S. B.; Cobb, G. P. Reproductive Effects of Hexahydro-1,3,5-trinitroso-1,3,5-triazine in
Deer Mice (Peromyscus maniculatus) during a Controlled Exposure Study. Environ. Toxicol. Chem. 2006, 25, 446-451.

18. Cotte-Rodriguez, J.; Takats, Z.; Cooks, R. G. Desorption Electrospray Ionization of Explosives on Surfaces: Sensitivity and Selectivity enhancement by Reactive Desorption Electrospray Ionization. Anal. Chem. 2005, 77, 6755-6764.

19. Cotte-Rodriguez, I.; Cooks, R. G. Non-proximate Detection of Explosives and Chemical Warfare Agent Simulants by Desorption Electrospray ionization Mass Spectrometry. Chem. Commun. (Camb.) 2006, 28 , 2968-2970.

20. Cody, R. B.; Laramee, J. A.; Durst, H. D. Versatile New Ion Source for the Analysis of Materials in Open Air under Ambient Conditions. Anal. Chem. 2005, 77, 2297-2302.

21. Zhao, X.; Yinon, J. Identification of Nitrate Ester Explosives by Liquid Chromatography-Electrospray Ionization and Atmospheric Pressure Chemical Ionization Mass Spectrometry. J. Chromatogr. A 2002, 977, $59-68$.

22. Gapeev, A.; Sigman, M.; Yinon, J. Liquid Chromatography/Mass Spectrometric Analysis of Explosives: RDX Adduct Ions. Rapid Commun. Mass Spectrom. 2003, 17, 943-948.

23. Sigman, M. E.; Armstrong, P. A.; MacInnis, J. M.; Williams, M. R. Equilibrium Partitioning Model Applied to RDX-Halide Adduct Formation in Electrospray Ionization Mass Spectrometry. Anal. Chem. 2005, 77, 7434-7441.

24. Cassada, D. A.; Monson, S. J.; Snow, D. D.; Spalding, R. F. Sensitive Determination of RDX, Nitroso-RDX Metabolites, and Other Munitions in Ground Water by Solid-phase Extraction and Isotope Dilution Liquid Chromatography-Atmospheric Pressure Chemical Ionization Mass Spectrometry. J. Chromatogr. A 1999, 844, 87-95.

25. Yinon, J. Detection of Explosives by Electronic Noses. Anal. Chem. 2003, $75,99 \mathrm{~A}-105 \mathrm{~A}$.

26. U.S. Environmental Protection Agency (USEPA). Test Methods for Evaluating Solid Waste Physical/Chemical Methods SW-846, Update III: Method 8330, Nitroaromatics and Nitramines by High Performance Liquid Chromatography; Office of Solid Waste: Washington, DC; 1996.

27. USEPA. Test Methods for Evaluating Solid Waste Physical/Chemical Methods SW-846, Update IVB: Method 8095, Explosives by Gas Chromatography; Office of Solid Waste: Washington, DC; 2000.

28. Walsh, M. E. Determination of Nitroaromatic, Nitramine, and Nitrate Ester Explosives in Soil by Gas Chromatography and an Electron Capture Detector. Talanta 2001, 54, 427-438.

29. Pan, X.; Zhang, B.; Cobb, G. P. Extraction and Analysis of Trace Amounts of Cyclonite (RDX) and Its Nitroso-Metabolites in Animal Liver Tissue Using Gas Chromatography with Electron Capture Detection (GC-ECD). Talanta 2005, 67, 816-823.

30. Monteil-Rivera, F.; Beaulieu, C.; Hawari, J. Use of Solid-phase Microextraction/Gas Chromatography-Electron Capture Detection for the Determination of Energetic Chemicals in Marine Samples. J. Chromatogr. A 2005, 1066, 177-187.

31. Sigman, M. E.; Ma, C.-Y. Detection Limits for GC/MS Analysis of Organic Explosives. J. Forensic Sci. 2001, 46, 6-11.

32. Sigman, M. E.; Ma, C.-Y.; Ilgner, R. H. Performance Evaluation of an In-Injection Port Thermal desorption/Gas Chromatographic/Negative Ion Chemical Ionization Mass Spectrometric Method for Trace Explosive Vapor Analysis. Anal. Chem. 2001, 73, 792-798.

33. McLuckey, S. A.; Goeringer, D. E.; Asan, K. E. High Explosives Vapor Detection by Atmospheric Sampling Glow Discharge Ionization/Tandem Mass Spectrometry. Technical Manuscript ORNL/TM-13166; Oak Ridge National Laboratory: Oak Ridge, TN; 1993.

34. Chakraborty, D.; Muller, R. P.; Dasgupta, S.; Goddard, W. A. A Detailed Model for the Decomposition of Nitramines: RDX and HMX. J. Comput.Aided Mater. Des. 2002, 8, 203-212.

35. Politzer, P.; Ma, Y. G. Noncovalent Intermolecular Energetics: RDX Crystal. Int. J. Quantum Chem. 2004, 100, 733-739.

36. Qasim, M.; Fredrickson, H.; McGrath, C.; Furey, J.; Bajpai, R. Theoretical Predictions of Chemical Degradation Reaction Mechanisms of RDX and Other Cyclic Nitramines Derived from Their Molecular Structures. SAR QSAR Environ. Res. 2005, 16, 203-218.

37. Wu, C. J.; Fried, L. E. Ab Initio Study of RDX Decomposition Mechanisms. J. Phys. Chem. A 1997, 101, 8675-8679.

38. Zhang, S.; Truong, T. N. Branching Ratio and Pressure Dependent Rate Constants of Multichannel Unimolecular Decomposition of Gas-Phase aHMX: An Ab Initio Dynamics Study. J. Phys. Chem. A 2001, 105, 2427-2434.

39. Woon, D. E.; Dunning, T. H. Gaussian Basis Sets for Use in Correlated Molecular Calculations. III. The Atoms Aluminum through Argon. J. Chem. Phys. 1993, 98, 1358-1371.

40. Becke, A. D. Density-Functional Thermochemistry. III. The Role of Exact Exchange. J. Chem. Phys. 1993, 98, 5648-5652.

41. Lee, C.; Yang, W.; Parr, R. G. Development of the Colle-Salvetti Correlation-Energy Formula into a Functional of the Electron Density. Phys. Rev. B 1988, 37, 785-789.

42. Curtiss, L. A.; Raghavachari, K.; Redfern, P. C.; Rassolov, V.; Pople, J. A. Assessment of Gaussian-2 and Density Functional Theories for the Computation of Ionization Potentials and Electron Affinities. J. Chem. Phys. 1998, 109, 7764-7776.

43. Gaussian03, Revision C. 02, Gaussian Inc.: Wallingford, CT; 2004. 